Article

\title{
Strategies to Improve Vaccination among At-Risk Adults and the Elderly in Italy
}

\author{
Giovanna Elisa Calabrò ${ }^{1,2}{ }^{-0}$, Alessia Tognetto ${ }^{1}\left(\mathbb{D}\right.$, Elettra Carini ${ }^{1}$, Silvia Mancinelli ${ }^{3}$, \\ Laura Sarnari ${ }^{4}$, Vittoria Colamesta ${ }^{1,5, *}$, Walter Ricciardi ${ }^{1,6}$ and Chiara de Waure ${ }^{7(\text { ) }}$
}

1 Section of Hygiene, Department of Life Sciences and Public Health; Università Cattolica del Sacro Cuore, 00168 Rome, Italy; giovannaelisa.calabro@gmail.com (G.E.C.); alessia.tognetto@gmail.com (A.T.); elettra.carini1@gmail.com (E.C.); walter.ricciardi@unicatt.it (W.R.)

2 VIHTALI (Value In Health Technology and Academy for Leadership \& Innovation), Spin-Off of Università Cattolica del Sacro Cuore, 00168 Rome, Italy

3 Department of Pneumological Sciences, Section of Pneumology, University of Pavia and Fondazione IRCCS Policlinico San Matteo, 27100 Pavia, Italy; silviamancinelli91@gmail.com

4 Regional Health Unit ASUR AV 3, Sanitary District of Macerata, 62100 Macerata, Italy; sarnari13@gmail.com

5 UOC Direzione Sanitaria S. Spirito e Nuovo Regina Margherita, Local Health Unit ASL RM1, 00193 Rome, Italy

6 Fondazione Policlinico Universitario A. Gemelli IRCCS, 00168 Rome, Italy

7 Department of Experimental Medicine, University of Perugia, 06132 Perugia, Italy; chiara.dewaure@unipg.it

* Correspondence: vittoria.colamesta@gmail.com

Received: 26 May 2020; Accepted: 1 July 2020; Published: 4 July 2020

check for updates

\begin{abstract}
The World Health Organization (WHO), the United States (US) Centers for Disease Control and Prevention (CDC), the European Center for Disease Control (ECDC), and the immunization guidelines of many countries issue vaccination recommendations for adults and the elderly. However, the uptake of vaccination in these groups is generally low due to several reasons. The present study aimed to identify strategies implemented in Italy in unconventional settings to promote vaccination against influenza, pneumococcal, and herpes zoster virus (HZV) infections among these subjects, i.e., the at-risk adult population and the elderly. We conducted a literature review and a survey of experts. The literature search yielded seven strategies; all of these concerned influenza vaccination, while three also addressed pneumococcal and HZV vaccination. The survey of experts identified 15 strategies; 10 regarded influenza vaccination, while four regarded pneumococcal vaccination and one regarded HZV vaccination. Most of the strategies were implemented in hospital clinics and rest homes. Regarding influenza and pneumococcal vaccinations, the target population mainly comprised at-risk adults, while the elderly represented the main target population for HZV vaccination. Our results show that, in Italy, there are initiatives aimed at promoting vaccination in unconventional settings, but further efforts are required to assess their effectiveness and to further extend them.
\end{abstract}

Keywords: HZV vaccination; influenza vaccination; pneumococcal vaccination; immunization strategies; elderly

\section{Introduction}

Vaccinations are effective and cost-effective tools for the prevention of infectious diseases. Nevertheless, a huge number of deaths today are caused by vaccine-preventable diseases (VPDs). According to the latest World Health Organization (WHO) data, vaccination prevents 2-3 million deaths every year [1]. While vaccination can benefit persons of all ages, it is especially important for those at higher risk of infectious diseases and their complications. As the immune system weakens with increasing age, many infectious diseases are more severe and more closely associated with long-term 
consequences in the elderly than in younger people [2]. Moreover, regardless of age, any health condition that weakens the immune system exposes the person to a greater risk of infectious diseases and their consequences [3]. Therefore, adults presenting with certain characteristics and particular chronic conditions (cardiovascular, respiratory, or metabolic diseases, immunodepression, etc.) are considered "at-risk". While awareness of childhood vaccination is well established, the importance of vaccination for the elderly and for at-risk individuals is not as well perceived. A recent Eurobarometer survey [4] revealed that, in Europe, only $85 \%$ of citizens believe that vaccines are effective in preventing infectious diseases (78\% among Italian respondents). Furthermore, almost half of the Italian population ( $48 \%$ vs. $29 \%$ of Europeans) believe that vaccinations are important only for children. Therefore, the prevention of infectious diseases in groups other than children is a challenging, yet fundamental, objective that public health systems should pursue in order to promote healthy aging $[5,6]$.

Immunization guidelines released by WHO, the United States (US) Centers for Disease Control and Prevention (CDC), the European Center for Disease Control (ECDC), and many countries include vaccination recommendations for adults and the elderly [7-9]. Vaccination against influenza and Streptococcus pneumoniae is generally recommended for at-risk adults and for the elderly; however, this definition is country-dependent ranging from $\geq 50$ years to $\geq 65$ years. Some countries, such as Austria, the Czech Republic, France, Greece, Italy, the United Kingdom (UK), and the United States of America (USA), also recommend vaccination against herpes zoster virus (HZV) for older adults [10]. Despite these recommendations, vaccination coverage in the elderly and at-risk groups remains unsatisfactory.

In Italy, the 2017-2019 National Immunization Plan (Piano Nazionale per la Prevenzione Vaccinale-PNPV) recommended specific vaccinations for the elderly, defined as those 65 years old and older, and at-risk adults [11]. These include influenza vaccination, pneumococcal vaccination (pneumococcal conjugate vaccine (PCV13), followed by a dose of polysaccharide vaccine (PPV23)), and the HZV vaccine. Furthermore, the PNPV set the following coverage targets: 75\% minimum and $95 \%$ optimal coverage for seasonal influenza vaccination, $75 \%$ for pneumococcal vaccination in 2019, and 50\% for HZV in 2019 [11]. However, these coverage targets remain unmet. According to data from the Italian Ministry of Health, influenza vaccination coverage among the elderly reached only $53.1 \%$ in the 2018/2019 season [12].

A wide range of factors may influence vaccination uptake. The magnitude of this phenomenon prompted the WHO to develop a set of tools (quantitative surveys, qualitative interviews, and related user guide) to investigate the reasons for low vaccination uptake, to improve coverage, and to evaluate interventions [13]. The general decline in coverage may be partly attributable to the so-called vaccine hesitancy, which is defined by the Strategic Advisory Group of Experts (SAGE) on WHO immunization as the tendency to delay or to refuse vaccination despite the availability of vaccination services [14]. Today, vaccine hesitancy constitutes a real threat to the health and well-being of citizens, as it undermines the effectiveness of immunization programs. It is, therefore, essential to develop skills at the local, national, and global levels in order to identify, monitor, and counteract vaccination hesitancy and to respond promptly to anti-vaccination movements in the event of disinformation or potentially adverse events [15]. According to the "Increasing Vaccination Model", facilitating access to vaccination can remove practical obstacles to the delivery of vaccination, and it is, therefore, important in the fight against low vaccination uptake [16]. However, other factors, such as complacency (failure to perceive the risks of disease), constraints (physical and psychological barriers), calculation (searching extensively for information), and aspects pertaining to collective responsibility (willingness to protect others) also play a role in explaining vaccination behavior [17].

The uptake of vaccination must be improved to achieve the objective to reduce the morbidity, mortality, loss of quality of life, and healthcare costs caused by VPDs [18], but the available evidence indicates that vaccination coverage in older adults and at-risk groups can be considerably improved. In this light, new vaccination strategies will be needed in order to achieve this objective. 
The present study aimed to identify and describe novel and unconventional strategies implemented in Italy, at the regional or national level, in order to promote vaccination among the elderly and at-risk populations, by facilitating access to vaccination in alternative settings, namely, occupational, recreational, and unconventional healthcare settings.

\section{Materials and Methods}

In this study, we conducted a literature review and a survey among regional vaccination referents and professionals in charge of vaccination departments in Italy.

The literature review was conducted by searching the MEDLINE database for the following search terms: vaccin* uptake, strategy*, campaign, policy, elderly, fragile, comorbidit*. The search was limited to articles written in English or Italian and published up to 11 March 2019. We also adopted the same search strategy in order to explore the "gray literature" and to investigate several institutional websites (WHO, WHO Europe, CDC, ECDC, Italian Ministry of Health, Italian National Institute of Health).

The inclusion criteria required that the articles should report vaccination strategies against influenza, pneumococcal diseases, and HZV, targeted at at-risk adult populations and the elderly (65 years of age or older) and carried out in unconventional settings in Italy (i.e., occupational and recreational settings or healthcare facilities other than those routinely involved in vaccinations, namely, local health authorities (LHA) and general practitioner (GP) offices).

In order to identify additional strategies, an online survey through Google Platform was launched; an e-mail invitation to participate was sent to 129 experts: directors of hygiene and public health departments and the regional vaccination referents of all Italian regions. The survey was conducted between 19 May 2019 and 16 June 2019, and two reminders were sent out in order to increase the response rate. The survey was also sent to the generic email addresses of Italian departments of prevention.

The survey, which was estimated to require about 15 minutes to complete, consisted of four sections:

(1) Demographic and professional information (Italian region and department of affiliation);

(2) General information on the implementation, at the regional level, of the PNPV and the introduction of an immunization information registry;

(3) A section focused on the three vaccinations of interest; interviewees were asked whether, to their knowledge, any strategy that met the eligibility criteria was implemented in the last five years in their region. This section was divided into three sub-sections, one for each of the vaccinations considered: influenza, pneumococcal, and HZV;

(4) A section collecting information on any strategy reported: target, setting, healthcare professionals involved, ways of inviting the target population, waiting time to receive vaccination, counseling and informative material, and final assessment. Further contacts and material (links, attached documents, regional deliberations, etc.) were also requested in order to evaluate the strategy in detail.

The survey was organized so that responses were specific to each of the vaccinations in question. Additional space was also provided in which to add information on further strategies as free text. Information on the region, setting, target population, and strategy type was assigned for each strategy reported. In addition, information on the health personnel involved, recruitment and scheduling, provision of counseling, registration of vaccination administration in the immunization information registry, and final assessment of the impact (if applicable) was collected for the strategies identified by consulting the experts.

The survey and the database generated from survey responses are available as supplemental data (Supplementary File S1) in native language. Hereby, we would like to clarify that this study did not need ethics committee approval as it relied on a review of the literature and on the collection of information on vaccination strategies set up at the regional/local level. 


\section{Results}

The literature review yielded seven vaccination strategies, implemented in four Italian regions (Table 1): three (43\%) in Lombardy, two (29\%) in Liguria, one (14\%) in Emilia-Romagna, and one (14\%) in Trentino-South Tyrol. All strategies concerned influenza vaccination, while three of them (43\%) also addressed pneumococcal and HZV vaccination (in Liguria, Emilia-Romagna, and Lombardy). Of the 654 studies identified through MEDLINE, none met the inclusion criteria. Therefore, all strategies were identified by searching the gray literature.

Regarding the consultation of experts, 19 replies (response rate: $14.7 \%$ ) were eventually collected from 10 Italian regions: four (21\%) from Apulia, three (16\%) from Liguria, three (16\%) from Lombardy, two (11\%) from Calabria, two (11\%) from Campania, one (5\%) from Friuli Venezia Giulia, one (5\%) from Lazio, one (5\%) from Marche, one (5\%) from Piedmont, and one (5\%) from Trentino-South Tyrol. A total of 20 vaccination strategies were reported, but only 15 of these were included in the final analysis (Table 2), as three strategies had healthcare professionals as the target population of the vaccination strategy and two did not provide sufficient information. The 15 strategies were implemented in five regions and one autonomous province (AP): five (33\%) in Lombardy, three (20\%) in Calabria, three $(20 \%)$ in Apulia, two (13\%) in the AP of Bolzano, one (7\%) in Friuli Venezia Giulia, and one (7\%) in Marche. Of the 15 strategies included, 10 (67\%) regarded influenza vaccination (three (30\%) in Calabria, two (20\%) in Lombardy, two (20\%) in Apulia, one (10\%) in Friuli Venezia Giulia, one (10\%) in Marche, and one (10\%) in the AP of Bolzano), four (27\%) regarded pneumococcal vaccination (two (50\%) in Lombardy, one (25\%) in Apulia, and one (25\%) in the AP of Bolzano), and one (7\%) regarded HZV vaccination (in Lombardy).

The main characteristics of the strategies, stratified by type of vaccination, are reported below. 
Table 1. Vaccination strategies identified by means of literature review.

\begin{tabular}{|c|c|c|c|c|}
\hline Vaccination Strategy & Region & Setting & Target Population & Type of Strategy \\
\hline \multirow{7}{*}{ Influenza vaccination } & Emilia-Romagna & $\begin{array}{l}\text { Cona Hospital (Ferrara); } \\
\text { Vaccination clinic in "SS.ma Annunziata" hospital, } \\
\text { Cento; } \\
\text { "Del Delta" Hospital (Lagosanto, Ferrara); } \\
\text { Argenta Hospital (Ferrara) }\end{array}$ & Pregnant women & Vax Day Hospital Presides: free access vaccinations \\
\hline & Liguria & $\begin{array}{l}\text { Hygiene Unit clinics in "San Martino" hospital } \\
\text { Pharmacies }\end{array}$ & $\geq 65$ years, adults with risk conditions & $\begin{array}{l}\text { Campaign promoted by Liguria Region and } \\
\text { A.Li.Sa., in collaboration with five Health } \\
\text { Authorities and Ligurian Hospitals }\end{array}$ \\
\hline & Liguria & Vaccination clinic in "Villa Scassi" hospital (Genova) & $\begin{array}{l}\text { Fragile hospitalized patients, pregnant women, and those } \\
\text { who live with immunosuppressed subjects }\end{array}$ & "Ospivax, the vaccinating hospital" Project \\
\hline & Lombardy & Dedicated clinics of some specialist departments & $\begin{array}{l}\geq 65 \text { years, adults with risk conditions, and pregnant women } \\
\geq 65 \text { years, adults with risk conditions, pregnant women, }\end{array}$ & Influenza vaccination campaign \\
\hline & Lombardy & Accredited socio-health and hospital facilities & $\begin{array}{l}\text { those working on livestock farms, healthcare personnel, and } \\
\text { public services personnel }\end{array}$ & Influenza vaccination campaign \\
\hline & Lombardy & $\begin{array}{l}\text { "San Camillo" rest home and other social and health } \\
\text { facilities }\end{array}$ & $\geq 65$ years, adults with risk conditions & Influenza vaccination campaign \\
\hline & Trentino-South Tyrol & Stand at the Autumn Fair & $\geq 65$ years, adults with risk conditions & Influenza vaccination campaign \\
\hline \multirow[t]{3}{*}{$\begin{array}{l}\text { Pneumococcal and } \mathrm{HZV} \\
\text { vaccinations }\end{array}$} & Emilia-Romagna & $\begin{array}{l}\text { Cona Hospital (Ferrara); } \\
\text { Vaccination clinic in "SS.ma Annunziata" hospital, } \\
\text { Cento; } \\
\text { "Del Delta" Hospital (Lagosanto, Ferrara); } \\
\text { Argenta Hospital (Ferrara) }\end{array}$ & People aged 65 and 66 & Vax Day Hospital Presides: free access vaccinations \\
\hline & Liguria & Vaccination clinic in "Villa Scassi" hospital (Genova) & \multirow{2}{*}{$\begin{array}{l}\text { Fragile hospitalized patients and those who live with } \\
\text { immunosuppressed subjects } \\
\geq 65 \text { years }\end{array}$} & "Ospivax, the vaccinating hospital" Project \\
\hline & Lombardy & Accredited socio-health and hospital facilities & & Free pneumococcal and HZV vaccination \\
\hline
\end{tabular}

Note: HZV: Herpes Zoster Virus; A.Li.Sa: Azienda Ligure Sanitaria della Regione Liguria. 
Table 2. Vaccination strategies identified by consulting experts.

\begin{tabular}{|c|c|c|c|c|c|c|c|c|c|c|c|}
\hline $\begin{array}{l}\text { Vaccination } \\
\text { Strategy }\end{array}$ & Region & Province & Target Population & Setting & Access to Vaccination & $\begin{array}{l}\text { Invitation to } \\
\text { Vaccination } \\
\text { Initiative }\end{array}$ & $\begin{array}{l}\text { Counseling } \\
\text { (Supporting } \\
\text { Information } \\
\text { Material) } \\
\end{array}$ & $\begin{array}{l}\text { Registration } \\
\text { in the } \\
\text { Vaccination } \\
\text { Registry? }\end{array}$ & $\begin{array}{l}\text { Strategy } \\
\text { Assessment }\end{array}$ & $\begin{array}{l}\text { Evaluation Parameters of the } \\
\text { Strategy }\end{array}$ & $\begin{array}{l}\text { Are the } \\
\text { Results } \\
\text { Public? }\end{array}$ \\
\hline \multirow{10}{*}{$\begin{array}{l}\text { Influenza } \\
\text { vaccination }\end{array}$} & Calabria & Crotone & $\begin{array}{l}\geq 65 \text { years, adults with } \\
\text { risk conditions }\end{array}$ & $\begin{array}{l}\text { Hospital clinic, health care } \\
\text { residence, pharmacy, prison } \\
\text { house, rest home }\end{array}$ & Paper booking & Invitation letter & No & No & No & N.A. & N.A. \\
\hline & Calabria & Cosenza & $\begin{array}{l}\geq 65 \text { years, adults with } \\
\text { risk conditions }\end{array}$ & $\begin{array}{l}\text { Hospital clinic, health care } \\
\text { residence, pharmacy, prison } \\
\text { house, rest home, parish } \\
\text { Mobile vaccination station, }\end{array}$ & $\begin{array}{l}\text { Paper, telephone, and } \\
\text { online booking }\end{array}$ & $\begin{array}{l}\text { Invitation letter, } \\
\text { text message }\end{array}$ & Yes (yes) & Yes & Yes & $\begin{array}{l}\% \text { uptake, vaccination coverage, } \\
\text { customer satisfaction }\end{array}$ & Yes \\
\hline & Calabria & Cosenza & $\begin{array}{l}\geq 65 \text { years, adults with } \\
\text { risk conditions }\end{array}$ & $\begin{array}{l}\text { hospital clinic, health care } \\
\text { residence, pharmacy, prison } \\
\text { house, rest home }\end{array}$ & $\begin{array}{l}\text { Paper, telephone, and } \\
\text { online booking }\end{array}$ & $\begin{array}{l}\text { Invitation letter, } \\
\text { text message }\end{array}$ & Yes (yes) & Yes & Yes & $\begin{array}{l}\% \text { uptake, vaccination coverage, } \\
\text { costs, customer satisfaction }\end{array}$ & Yes \\
\hline & $\begin{array}{l}\text { Friuli Venezia } \\
\text { Giulia }\end{array}$ & Pordenone & $\begin{array}{l}\geq 65 \text { years, adults with } \\
\text { risk conditions }\end{array}$ & $\begin{array}{l}\text { Hospital clinic, health care } \\
\text { residence, pharmacy, rest home }\end{array}$ & $\begin{array}{l}\text { Telephone and online } \\
\text { booking }\end{array}$ & $\begin{array}{l}\text { By telephone } \\
\text { contact, by email }\end{array}$ & Yes (yes) & Yes & Yes & $\begin{array}{l}\text { \% uptake, vaccination coverage, } \\
\text { costs }\end{array}$ & Yes \\
\hline & Lombardy & Milan & $\begin{array}{l}\geq 65 \text { years, adults with } \\
\text { risk conditions }\end{array}$ & $\begin{array}{l}\text { Hospital ward, hospital clinic, } \\
\text { health care residence, rest home }\end{array}$ & N.R. & $\begin{array}{l}\text { Media, posters, } \\
\text { website }\end{array}$ & Yes (yes) & Yes & Yes & $\begin{array}{l}\% \text { uptake, vaccination coverage, } \\
\text { costs }\end{array}$ & No \\
\hline & Lombardy & Sondrio & $\begin{array}{l}\geq 65 \text { years, adults with } \\
\text { risk conditions }\end{array}$ & $\begin{array}{l}\text { Hospital clinic, health care } \\
\text { residence, rest home }\end{array}$ & Telephone booking & Invitation letter & Yes (no) & Yes & N.R. & N.A. & N.A. \\
\hline & Marche & Ancona & $\begin{array}{l}\text { Adults with risk } \\
\text { conditions }\end{array}$ & $\begin{array}{l}\text { Mobile vaccination station, center } \\
\text { for diabetes }\end{array}$ & N.R. & N.R. & Yes (yes) & No & No & N.A. & N.A. \\
\hline & Apulia & Foggia & $\begin{array}{l}\text { Adults with risk } \\
\text { conditions }\end{array}$ & $\begin{array}{l}\text { Hospital ward, hospital clinic, } \\
\text { health care residence, rest home }\end{array}$ & $\begin{array}{l}\text { Telephone and online } \\
\text { booking }\end{array}$ & $\begin{array}{l}\text { Invitation letter, } \\
\text { by email }\end{array}$ & Yes (no) & Yes & Yes & $\begin{array}{l}\text { \% uptake, vaccination coverage, } \\
\text { customer satisfaction, costs }\end{array}$ & Yes \\
\hline & Apulia & Bari & Pregnant women & Hospital clinic & Telephone booking & $\begin{array}{l}\text { By telephone } \\
\text { contact }\end{array}$ & Yes (yes) & Yes & Yes & $\begin{array}{l}\text { \% uptake, customer satisfaction, } \\
\text { adverse event with call after } 48 / 72 \mathrm{~h}\end{array}$ & No \\
\hline & $\begin{array}{l}\text { Trentino-South } \\
\text { Tyrol }\end{array}$ & Bolzano & $\begin{array}{l}\geq 65 \text { years, adults with } \\
\text { risk conditions }\end{array}$ & $\begin{array}{l}\text { Hospital ward, hospital clinic, } \\
\text { rest home }\end{array}$ & $\begin{array}{l}\text { Paper, telephone, and } \\
\text { online booking }\end{array}$ & N.R. & No & Yes & Yes & $\%$ uptake, vaccination coverage & Yes \\
\hline \multirow{4}{*}{$\begin{array}{l}\text { Pneumococcal } \\
\text { vaccination }\end{array}$} & Lombardy & Milan & $\begin{array}{l}\text { Adults with risk } \\
\text { conditions }\end{array}$ & Hospital ward, hospital clinic & N.R. & N.R. & Yes (yes) & Yes & Yes & Vaccination coverage, costs & No \\
\hline & Lombardy & Sondrio & $\begin{array}{l}\geq 65 \text { years, adults with } \\
\text { risk conditions }\end{array}$ & $\begin{array}{l}\text { Hospital clinic, health care } \\
\text { residence, rest home }\end{array}$ & Telephone booking & $\begin{array}{l}\text { Invitation letter, } \\
\text { by telephone } \\
\text { contact }\end{array}$ & Yes (no) & Yes & N.R & N.A & N.A \\
\hline & Apulia & Foggia & $\begin{array}{l}\text { Adults with risk } \\
\text { conditions }\end{array}$ & $\begin{array}{l}\text { Hospital ward, hospital clinic, } \\
\text { health care residence, rest home }\end{array}$ & $\begin{array}{l}\text { Telephone and online } \\
\text { booking }\end{array}$ & $\begin{array}{l}\text { Invitation letter, } \\
\text { by e-mail }\end{array}$ & Yes (yes) & Yes & Yes & $\begin{array}{l}\% \text { uptake, vaccination coverage, } \\
\text { costs }\end{array}$ & Yes \\
\hline & $\begin{array}{l}\text { Trentino-South } \\
\text { Tyrol }\end{array}$ & Bolzano & $\geq 65$ years & Hospital clinic, rest home & $\begin{array}{l}\text { Paper, telephone, and } \\
\text { online booking }\end{array}$ & Invitation letter & No & Yes & Yes & $\%$ uptake, vaccination coverage & Yes \\
\hline $\begin{array}{l}\mathrm{HZV} \\
\text { vaccination }\end{array}$ & Lombardy & Sondrio & $\begin{array}{l}\geq 65 \text { years, adults with } \\
\text { risk conditions }\end{array}$ & Hospital clinic & $\begin{array}{l}\text { Paper and telephone } \\
\text { booking }\end{array}$ & $\begin{array}{l}\text { By telephone } \\
\text { contact }\end{array}$ & Yes (no) & Yes & N.R. & N.A. & N.A. \\
\hline
\end{tabular}

Note: N.R.: not reported; N.A.: not applicable; HZV: Herpes Zoster Virus. 


\subsection{Influenza Vaccination Strategies}

Seventeen influenza vaccination strategies met the inclusion criteria, seven from the literature review (Table 1) and 10 from the consultation of experts (Table 2). The settings of the strategies were hospital clinics (77\%), rest homes (53\%), healthcare residences $(47 \%)$, pharmacies $(29 \%)$, hospital wards $(18 \%)$, prisons $(18 \%)$, mobile vaccination stations $(12 \%)$, accredited socio-health facilities $(12 \%)$, a center for diabetes $(6 \%)$, a parish $(6 \%)$, a hospital facility $(6 \%)$, and a stand at a fair $(6 \%)$. The target populations were at-risk adults $(100 \%)$, pregnant women $(6 \%)$, and subjects aged $\geq 65$ years $(71 \%)$. The strategies identified from the survey of experts utilized invitation letters in $50 \%$ of cases and provided counseling in $80 \%$. The health personnel involved in the strategies were medical doctors $(100 \%)$, nurses $(90 \%)$, and other health professionals (40\%). A final assessment was scheduled in $70 \%$ of cases; in $86 \%$ of these, vaccination coverage was included in the evaluation criteria. Interestingly, customer satisfaction was also considered in $57 \%$ of the strategies that underwent final assessment. The results were made public in $71 \%$ of cases.

\subsection{Pneumococcal Vaccination Strategies}

Seven pneumococcal vaccination strategies met the inclusion criteria, three from the literature review (Table 1) and four from the consultation of experts (Table 2). The settings were hospital clinics $(86 \%)$, rest homes $(43 \%)$, hospital wards $(29 \%)$, healthcare residences $(29 \%)$, and an accredited socio-health and hospital facility (14\%). The target populations were at-risk adults (57\%) and subjects aged $\geq 65$ years $(57 \%)$. The strategies identified from the survey of experts utilized invitation letters and provided counseling in 75\% of cases. The health personnel involved in the strategies were medical doctors and nurses ( $100 \%$ of cases), and other health professionals $(25 \%)$. A final assessment was made for all the strategies, and vaccination coverage was included among the criteria evaluated in $75 \%$ of cases. In two of these latter cases $(67 \%)$, the results of the assessment were made public.

\subsection{HZV Vaccination Strategies}

A total of four HZV vaccination strategies were included in the study, three from the literature review (Table 1) and one from the consultation of experts (Table 2). The settings of the strategies were hospital clinics $(75 \%)$ and an accredited socio-health and hospital facility $(25 \%)$. The target populations were at-risk adults $(50 \%)$ and subjects aged $\geq 65$ years $(75 \%)$. The only HZV vaccination strategy identified from the consultation of experts utilized telephone invitations, included counseling, and involved medical doctors and nurses. As for its final assessment, no information was provided.

\section{Discussion}

The present study identified and described strategies implemented in Italy in unconventional settings in order to promote influenza, pneumococcal, and HZV vaccinations among at-risk adults and the elderly.

Most of the strategies identified were aimed at promoting influenza vaccination; relatively few concerned pneumococcal and/or HZV vaccinations. The main settings identified were hospital clinics, rest homes, and healthcare residences, this last setting being mainly used for influenza vaccination. In a smaller percentage of cases, pharmacies, hospital wards, prisons, mobile vaccination stations, and accredited socio-health facilities were involved. Finally, in individual strategies, a center for diabetes, a parish, a hospital facility, and a stand at a fair were the settings involved. Not all strategies considered both targets (at-risk adults and the elderly). Indeed, with regard to influenza and pneumococcal vaccinations, the target population was mainly at-risk adults, while, in the case of HZV vaccination, the main target population was subjects aged $\geq 65$ years.

Although many strategies to promote vaccinations were introduced in recent years, and the importance of vaccination is well recognized from the public health viewpoint, many European countries are witnessing a decline in coverage, with considerable repercussions on healthcare systems, 
society, and the economy. Moreover, despite the recommendations issued by health institutions, vaccination coverage in the elderly and at-risk adults remains unsatisfactory. For instance, during the 2017/2018 flu season, the European Regional Office of the WHO and the ECDC issued a warning about the low uptake of influenza vaccination in Europe, particularly among people who were at high risk of developing complications, such as the elderly [19].

The declining vaccination coverages could be partly attributable to vaccination hesitancy, which is nevertheless a complex phenomenon that can have various causes. This is why it is important to work on different levels, including the removal of barriers to vaccination. In this context, novel vaccination strategies relying on new ways of recruiting patients, such as those identified in this study, would require attention.

In all the European countries, Italy among them, it is also essential to reach optimal levels of coverage for the purpose of achieving herd immunity against specific VPDs [20]. Only in this way is it possible to curb the circulation of the micro-organism responsible for the disease, thereby ensuring protection of the whole community. The impact of vaccination on the population's health is, therefore, considerable in terms of limiting the damage caused by VPDs or their complications and reducing both direct and indirect costs [21].

In this context, vaccination is especially important for people at higher risk. Given that life expectancy is increasing and that the worldwide number of people over 60 years of age is expected to double by 2050, reaching 2.1 billion [22], and considering that the immune system weakens with increasing age, the health strategy adopted toward this aging population will have major economic and health implications in the coming years. If the potential of vaccines to reduce the morbidity, mortality, loss of quality of life, and healthcare costs caused by VPDs is to be realized, the uptake of vaccination by at-risk adults and the elderly must be improved [18].

To the best of our knowledge, this is the first study to collate Italian strategies implemented in unconventional settings to promote vaccination against influenza, pneumococcal diseases, and $\mathrm{HZV}$; its results shed light on existing potential strategies that can help reaching desirable coverage targets. The study was based on a literature review and the consultation of experts and, although the rate of response to the survey was low, we obtained a good overview from several Italian regions. Nevertheless, the heterogeneity of strategies identified and the fact that relevant information was sometimes lacking did not allow us to make a precise comparison among strategies. In addition, because of heterogeneity and owing to the lack of quantitative measures, we were unable to assess and compare the effectiveness of the various strategies. However, the awareness of existing strategies in this field is an essential starting point in order to both identify vaccinations that still require further efforts, namely, pneumococcal and HZV vaccinations, and better design future initiatives. In particular, our research summarized some characteristics that will be useful for the implementation of further strategies to promote influenza, pneumococcal, and HZV vaccinations among at-risk adult populations and the elderly.

\section{Conclusions}

Vaccination of the elderly and at-risk adults constitutes a fundamental measure that public health systems should strengthen in order to protect these subjects from VPDs and their complications. Given that vaccination coverage rates are still far below the established targets, new strategies to promote vaccination are needed. Unconventional settings should be utilized in order to broaden the vaccination of elderly and at-risk individuals.

Supplementary Materials: The following are available online at http://www.mdpi.com/2076-393X/8/3/358/s1: File S1: Brave Project Survey: Best practices improving vaccination coverage among at-risk adults and the elderly (in native language). 
Author Contributions: Conceptualization, W.R., C.D.W., G.E.C., and V.C.; methodology, C.D.W. and G.E.C.; data analysis, A.T., E.C., S.M., and L.S.; writing-original draft preparation, A.T., E.C., V.C., L.S., and S.M.; writing-review and editing, C.D.W. and G.E.C.; supervision, W.R., C.D.W and G.E.C. All authors have read and agreed to the published version of the manuscript.

Funding: The BRAVE project (Best pRActices improving Vaccination coverage among at-risk adults and the Elderly) was supported and funded by Seqirus S.r.l.

Acknowledgments: The authors of this paper acknowledge the survey participants and the experts involved in the BRAVE project.

Conflicts of Interest: The authors declare no conflicts of interest.

\section{References}

1. World Health Organization. Immunization Coverage. Available online: https://www.who.int/news-room/ fact-sheets/detail/immunization-coverage (accessed on 11 April 2020).

2. Janssens, J.P. Pneumonia in the elderly (geriatric) population. Curr. Opin. Pulm. Med. 2005, 11, $226-230$. [CrossRef] [PubMed]

3. Pera, A.; Campos, C.; López, N.; Hassouneh, F.; Alonso, C.; Tarazona, R.; Solana, R. Immunosenescence: Implications for response to infection and vaccination in older people. Maturitas 2015, 82, 50-55. [CrossRef] [PubMed]

4. Special Eurobarometer 488. Europeans' Attitudes towards Vaccination. Available online: https://ec.europa. eu/health/sites/health/files/vaccination/docs/20190426_special-eurobarometer-sp488_en.pdf (accessed on 13 April 2019).

5. Coll, P.P.; Costello, V.W.; Kuchel, G.A.; Bartley, J.; McElhaney, J.E. The Prevention of Infections in Older Adults: Vaccination. J. Am. Geriatr. Soc. 2020, 68, 207-214. [CrossRef] [PubMed]

6. Esposito, S.; Principi, N.; Rezza, G.; Bonanni, P.; Gavazzi, G.; Beyer, I.; Sulzner, M.; Celentano, L.P.; Prymula, R.; Rappagliosi, A.; et al. WAidid-EVASG Panel on vaccination of 50+. Vaccination of 50+ adults to promote healthy ageing in Europe: The way forward. Vaccine 2018, 36, 5819-5824. [CrossRef] [PubMed]

7. World Health Organization. WHO Recommendations for Routine Immunization-Summary Tables. Available online: https://www.who.int/immunization/policy/immunization_tables/en/ (accessed on 13 April 2020).

8. Centers for Disease Control and Prevention. Vaccine Information for Adults. Available online: https: //www.cdc.gov/vaccines/adults/index.html (accessed on 13 April 2020).

9. European Centre for Disease Control. Vaccine Schedules in All Countries of the European Union. Available online: https://vaccine-schedule.ecdc.europa.eu/ (accessed on 13 April 2020).

10. European Centre for Disease Prevention and Control. Vaccine Schedule. Available online: http://vaccineschedule.ecdc.europa.eu/Pages/Scheduler.aspx (accessed on 13 April 2019).

11. Italian Health Ministry. National Preventive Vaccination Plan 2017-2019. Available online: http://www. gazzettaufficiale.it/eli/id/2017/02/18/17A01195/sg (accessed on 13 April 2020).

12. Italian Health Ministry. Vaccination Coverage. Influenza. Available online: http://www.salute.gov.it/portale/ influenza/dettaglioContenutiInfluenza.jsp?lingua=italiano\&id=679\&area=influenza\&menu=vuoto (accessed on 13 April 2020).

13. World Health Organization. Improving Vaccination Demand and Addressing Hesitancy. Available online: https://www.who.int/immunization/programmes_systems/vaccine_hesitancy/en/ (accessed on 13 April 2020).

14. World Health Organization. Report of the Sage Working Group on Vaccine Hesitancy. Available online: https:/www.who.int/immunization/sage/meetings/2014/october/1_Report_WORKING_ GROUP_vaccine_hesitancy_final.pdf (accessed on 13 April 2020).

15. European Centre for Disease Prevention and Control. Catalogue of Interventions Addressing Vaccine Hesitancy. Available online: https:/www.ecdc.europa.eu/sites/portal/files/documents/Catalogueinterventions-vaccine-hesitancy.pdf (accessed on 13 April 2020).

16. World Healh Organization. Increasing Vaccination Model. Available online: https://www.who. int/immunization/programmes_systems/Increasing_Vaccination_Model-WHO.PDF?ua=1 (accessed on 13 April 2020). 
17. Betsch, C.; Schmid, P.; Heinemeier, D.; Korn, L.; Holtmann, C.; Böhm, R. Beyond confidence: Development of a measure assessing the 5C psychological antecedents of vaccination. PLoS ONE 2018, 13, e0208601. [CrossRef] [PubMed]

18. Ozawa, S.; Portnoy, A.; Getaneh, H.; Clark, S.; Knoll, M.; Bishai, D.; Yang, H.K.; Patwardhan, P.D. Modeling the economic burden of adult vaccine-preventable diseases in the United States. Health Aff. 2016, 35, 2124-2132. [CrossRef] [PubMed]

19. European Center for Disease Control (ECDC). Low Uptake of Seasonal Influenza Vaccination in Europe May Jeopardize Capacity to Protect People in Next Pandemic. Available online: https://ecdc.europa.eu/en/ news-events/low-uptake-seasonal-influenza-vaccination-europe-may-jeopardise-capacity-protect-people (accessed on 13 April 2020).

20. Audisio, R.; Icardi, G.; Isidori, A.M.; Liverani, C.; Lombardi, A.; Mariani, L.; Mennini, F.S.; Mitchell, D.A.; Peracino, A.; Pecorelli, S.; et al. Public health value of universal HPV vaccination. Crit. Rev. Oncol. Hematol. 2016, 97, 157-167. [CrossRef] [PubMed]

21. Nymark, L.S.; Sharma, T.; Miller, A.; Enemark, U.; Griffiths, U.K. Inclusion of the value of herd immunity in economic evaluations of vaccines. A systematic review of methods used. Vaccine 2017, 35, 6828-6841. [CrossRef] [PubMed]

22. United Nations. World Population Prospects: The 2017 Revision. Available online: https://www. un.org/development/desa/publications/world-population-prospects-the-2017-revision.html (accessed on 13 April 2020).

(C) 2020 by the authors. Licensee MDPI, Basel, Switzerland. This article is an open access article distributed under the terms and conditions of the Creative Commons Attribution (CC BY) license (http://creativecommons.org/licenses/by/4.0/). 